\title{
Investigating EFL learners' speaking achievement taught by modified role play at English speaking class
}

\author{
Siti Farhana 1, Flora Flora', Muhammad Sukirlan'3 \\ English Department, Faculty of Education, Lampung University, Indonesia \\ Correspondence: sitifarhana962@gmail.com ${ }^{1}$
}

\begin{abstract}
This study investigated the effect of modified role play on students' speaking achievement. There were 28 students involved in the research. The sample was divided into two categories, one of which was designated as experimental and the other as control. Statistical analysis was used to interpret the data derived from the speaking test. The data were collected using pre and post-test. The pretest was administered at the start of the treatment, and again after 3 meetings of modified Role Play. In conducting the research, the researcher used a speaking test rubric to evaluate the students' speaking achievement which covered five components of speaking, such as fluency, grammar, vocabulary, pronunciation, and comprehensibility. The results showed that The mean score of experimental group in post-test and control group were significantly different. The mean score of post-test in experimental group $(24,571)$ was higher than control group (20,143).The findings indicated that the students in the experimental group had performed better than students in control group.
\end{abstract}

Keywords: modified role play, speaking achievement, EFL learners

\section{Introduction}

Speaking is one of the skills in English language, it is fundamentally an instrument act. An act of communication through speaking is an effective way to deliver the ideas directly and it can prevent the misunderstanding in communiation. Chaney (1998) pointed out that speaking is the process of constructing and exhanging the meaning through the use of verbal and nonverbal symbols in various situations. Speaking is one of the most substantial skills among all four language skills, because the person who learns a language is called the user of that language (Ur, 1996). The purpose of learning a language is the way people can implement it as a communication tool. For a long time, students do drill practice and memorize the conversations, but now they should learn how 
to express their opinions. However, learning to speak is assured not easy. Pollard (2008) pointed out that the most difficult aspects for students to master is speaking skill (p.34). Spoken English is an aspect that is difficult for students to master because they do not have sufficient knowledge of English (environmental factors), rarely use spoken English practice in daily life (they can communicate in their native language instead of English), and feel embarrassed to produce the words. In addition, Harris (1981) defines spoken language as an obscure skill that demand to be used with various competence at the same time (p. 81). In speaking, there are 5 aspects that must be learned and mastered in order to communicate properly. There are pronunciation, grammar, fluency, vocabulary, and comprehension. Richards and Rodgers (2001) believe that learners will encounter some types of problems when learning ESL oral skills (p. 160). One of the problems is that students' take too long to construct the words.

In short, English teaching activities need to adapt to an environment that encourages students to actively speak up in the class as well as boost students' confidence in speaking. To achieve the learning aim, the teacher should be innovative in selecting teaching methods that enable students to speak up more. Cook (2008) suggests using activities thatforce the students to use communication strategies whether they want to or not. According to Bilbrough (2007) students need to practice to communicate using language. In addition, Scrivener (2005) also pointed out that it is important empowering and encouraging students to speak because it will be a beneficial thing when students can communicate by using language learned. Furthermore, Richard and Renandya (2002) discovered that communication derives from interaction, so teachers should encourage students to communicate openly and provide them with appropriate topics, with a discussion or phrase acceptance process serving as the key to teaching the language of communication. In short, teaching English must include an environment that allows students to engage in speaking as well as a meaningful and adaptable activity in many situations. Role play is one of the practices that encourage students to communicate.

Role play is an acting out technique that requires students to play a role in certain situation and allows students to "become" anyone or imagine a specific situation, with students being able to improvise the dialogue or create statements and scenarios as in the real world. Role play is a strategy that force students to perform specific roles by speaking, acting, and sharing (Altun, 2015). Meanwhile, Qing (2011) found that role playing is defined as a simulation of real-life scenarios. Communication skills are built through role play, and students are encouraged to master them through interaction exercises (Afdillah, 2015). The study was proposed by Arifin and Russia (2013). They explored how role-playing would help students develop their speaking skills. High school students were the research sample. The result showed that the students' speaking ability improved after implementing role playing. In addition, the use of role play in teaching speaking 
provides a fun and engaging environment that enables students to share their ideas and opinions. Another study on the implementation of role playing was proposed by Krebt (2017). The study investigated the impact of the use of role playing in teaching speaking. University students are an example of students. The study divided the participants into two groups: experimental and control. There were two lessons and a discussion held during the study. According to the findings, students in the experimental group improved more than those in the control group. This suggests that incorporating role play into the classroom will provide students with a significant amount of speaking practice, allowing them to develop their speaking abilities.

Many previous studies have explored the importance of applying role play techniques to the student. Altun (2015) investigated the use of role playing in the classroom. He discovered that role play can provide a relaxing environment in which students can enjoy using language. The results showed that role play enables learners to gain confidence, strengthens motivation and promotes the speaking skills of language learners. Another study is promoted by Rahman, Abdul \& Maaruf (2018) that examined the effect of role play to improve students' speaking achievement. The result showed that the students favoured the roleplaying technique. Furthermore, the results of the observation revealed that the students seemed braver and more optimistic while speaking. This is evidenced by their participation in class conversations, discussions, pre-class performances, pronunciation, fluency and a sense of confidence in speaking.

Although the theoretical background of role-playing assumes that there are many advantages of role-playing in English classrooms, only some researches have shed light on the students' sides concerning role play activity. In contrast to the the positive result of role play, some limitations in role play strategy need to be investigated. Huang (2008), Livingstone (1983), Shaftel et al. (1967) mentioned the main steps of role-playing into four steps which are teacher preparation, students' preparation, role-play, and debriefing. In the third step of role-play activity according to Milarisa (2018) Some lecturers believe that there are too many disadvantages in using role-playing. For example, the activities requires a lot of time and cause embarrassment for students, they might be afraid of being laughed at by their peers, or they might assume they have lost control of the classroom. Benabadji (2007) also hinted that the problem of class management in role-playing arises when only a few students participate in roleplaying and lose control of the class, and when all students do not interact spontaneously, learning opportunities will be reduced. Various obstacles to roleplaying include the time limit of practice, the difficulty of writing interesting scripts, the active participants, encountering negative reactions when recruiting voluntary actors/actresses, and redundancy in the game (when the students forget the dialogue) and also audience boredom (Altun, 2015). 
Overcoming the problems in role play activity, there is a need to add a new procedure in role play to develop the students' ability to communicate. There are a variety of materials available to help students develop their speaking skills. Successful communication especially role play requires "turn-taking"-skills and meaningful real-life communicative tasks. These can be trained through IMPROV because turn-taking is an essential mechanism of IMPROV. IMPROV is a theatrical performance without a given storyline and dialogue. IMPROV is defined by unplanned collaborative performance (Halpern, Close, \& Johnson, 1994) where process and product occur (Sawyer, 2000; Sowden, Clements, Redlich, \& Lewis, 2015). This material and games have been used in several fields such as business, company, and workshop for leadership training. IMPROV exercises prepare you for the turn-taking that's required when you speak to someone in the real world because you're simultaneously sharpening your listening and speaking skills. According to Florea (2011), improvisational activities like IMPROV help students achieve three key goals while speaking: student pronunciation improves, correct usage of a grammatical structure is strengthened, and vocabulary practice is increased. The structure of IMPROV supports instructional strategies and approaches that successfully engage as well as re-engage students with a history of failure or who have become marginalized (Smith \& McKnight, 2009; Yaffe, 1989). IMPROV card is used in the middle of a conversation. In general role play, the students will face defining situations for the role they take. IMPROV card is filled with situations or scenarios. The IMPROV card is like the situation skit card for general role play. The difference is the general roleplay will use the card in the beginning before dialogue starts, but the IMPROV card will be used in the middle of a conversation. The students will take the role as usual and do the conversation but in the middle, they will get an IMPROV card based on the real situation life for making the role play more interesting.

The implementation of improvisation techniques may bring some benefits. According to Berlinger (2000), improvisation would encourage students to generate informative and comprehensive ideas, extend their vocabulary, regularly practice language skills, and develop greater fluency, all while learning about different social values. The environment and culture of the environment, participating in such activities can enhance students' confidence in their learning ability, which is an important part of successful language learning. Besides, Aswad (2017) also proved that improvisations technique can improve students' oral English skills. According to the results of the evaluation, the students' oral performance increased. Roleplay has been integrated with a variety of materials and technologies. A study from Krisdiana, Irawati, and Kadarisman (2018) conducted research on the integration of role playing and word cards. Research findings show that the combination of role-playing and vocabulary cards can help improve students' oral communication skills. Another study from Fongl, 
Bhattacharyyal, and Nordin (2018) examined the effectiveness of the "Time Out" role play technique hat improves speaking activity in ESL class. The researchers used a qualitative study design in which 94 students from a secondary school in Perak (Grades 4 and 5) were exposed to this task in the classroom. The findings of this study revealed that time-out role-playing is effective at achieving the goals outlined in the Oral Proficiency in English for Secondary Schools (OPS-English) and the National ESL Communication Aspirations. The result from the previous study shows positive effect by combining role play with other material and technique. Unfortunately, the combination of role play and improvisation has not been explored yet since it is indicated as improvised role play. With the innovation of IMPROV activity such as IMPROV card, the result of students' speaking skill can be different.

In short, the implementation of role play in teaching speaking needs to be modified to see broad spectrum of speaking in the class and to make communication-based on real-life situation. This is the purpose of using communication in daily basis. So, the students can interact naturally. Hence, the procedures are divided into three core steps; (1) Role Play with the role and conversation, (2) IMPROV card will be given in the middle of the conversation, and the last (3) result of the conversation.

Concerning the explanation and the previous research above, a modified role-play strategy will motivate students' speaking activity that Role Play provides them a clear way to express the idea freely and use the imagination in different contexts and situations about their oral utterances deeply. Therefore, the researcher proposes a modified Role Play strategy, which is in line with the approach of Role Play and IMPROV card, to make the output better. It will also stimulate students' ideas in speaking.

\section{Literature review}

\section{Role Play}

Ladousse (1995: 5) explained that when students take on a "character," they are playing a specific role in a specific situation (self or others). "Playing" refers to students acting out a part in a safe setting, where they are encouraged to be as imaginative and fun as possible. In role-playing, participants represented and experienced certain types of roles known in daily life (Scarcella and Oxford in Tompkins, 1998). Students pretend to be in various social environments and play various social roles. In role-playing activities, teachers provide learners with information, such as who they are, their thoughts or feelings (Harmer, 1984: 352). In addition, Ladousse (1995: 5) stated in his book that role-playing will build selfconfidence rather than destroy it. This means that they assume that all learners will enjoy it and will not feel any tension. However, we also need to treat learners as individuals with different personalities and learning styles, which may affect 
their performance. This is consistent with Dornyei (2005: 25), who believes that individual differences in second language acquisition and use are more important than mother tongue learning because we find that second language learners have greater differences in learning outcomes and language use characteristics Higher than their L1 counterparts. They assume "characters" in the dialogue, just like in real life. The learner has the opportunity to take action and interact. It encourages their thinking and creativity. In a given situation or environment, it also requires students to exert their imagination in order to play an important role. The second type of role is where the students play their roles in different situations that may or may not have had direct experience. Examples in this category are customer complaints or passengers requesting information. The third type is a common situation that can trigger students to respond directly and it is easy to play because the teacher has such a wide range of indirect experiences for them. Ladousse (1995: 6-7) explains several reasons why we use role-play in speaking activity. They are:

1. Role play will bring a variety of perspectives into the classroom.

2. Role play situates students in a situation where they need to use and develop the language in stages. These stages are necessary to deepen the relationship, but are often overlooked in our curriculum.

3. Some people learn English as the preparation for a specific role in their lives.

4. Role play helps many shy students by providing them with masks.

5 . The most major point to use role play is that it is enjoyable.

\section{Modified Role Play}

Role-playing strategies have been used for a long time, and many experts have developed role-playing strategies. According to Livingstone (1983), there are "role-play checklists": selection, preparation, class role-play preparation, roleplay and follow-up. Richard (in Tompkins, 1985): A different method was used. He proposed six steps for role-playing: initial tasks, model dialogue, learning to practice role-playing with role cards, follow-up, and repeating sequences. Ladousse (1987, in Tompkins) also has a different role-playing program, which she calls "The Island Game", with 11 role-playing factors, including level, time, goal, language, organization, preparation, and warm-up. , Procedures, follow-up measures, instructions and changes.

The steps for role play by several experts are a bit the same as for preparation, role play and feedback. These 3 steps are the main elements of your role-play strategy. One of the biggest challenges with the role play technique is to get all learners to participate and be truly involved. Somehow in the 'role-play or role-play' stage, the researcher found problems with student participation. Sometimes for advanced learners this technique will be boring, and for lower learners the role player will be like a robot. they have no intention of naturally 
engaging in conversation.To overcome those problems, the researcher will modified the step in role play with improv card.

IMPROV comes from improvisation theatre activity. IMPROV is a theatrical performance without a specific plot and dialogue. IMPROV is defined as an unplanned collaborative activity (Halpern, Close, \& Johnson, 1994) in which processes and products take place (Sawyer, 2000; Sowden, Clements, Redlich \& Lewis, 2015). This material and games have been used in many areas such as business, company and leadership training workshops. IMPROV exercises prepare students for the reordering that is required when they are talking to someone in the real world as improve the listening and speaking skills at the same time. The IMPROV framework supports strategies and teaching methods that can successfully attract and re-attract students with a history of failure or marginalization (Smith \& McKnight, 2009; Yaffe, 1989). IMPROV card is filled with situation or scenarios. In the IMPROV card, it is like the situation skit card for general role play. The difference is the general role play will use the card in the beginning before dialogue start, but IMPROV card will be used in the middle of conversation. The students will take the role as usual and do the conversation but in the middle they will get IMPROV card based on the real situation life for making the role play more interesting. the implementation of improvisations technique can yield many benefits for students. In additionAltun (2015) conducted a case study on the use of role-playing activities in order to determine the benefits of such activities for language learning. Role-playing games, according to others, will provide students with a calming atmosphere while also allowing them to enjoy the enjoyment of using the language. The results of the survey indicate that role-playing activities help students develop their selfconfidence, motivation, and oral expression skills in foreign language learners. Aliakbari and Jamalvandi (2010) pointed out that by using role-playing, second language learners can experience various actual situations of using languages and words. As their mastery of the language improves, they can be easily apply the language to new situations. Improvisational exercises enhance the grammatical structure, and when students understand the reasons for the exercises, they usually participate well (Pamela, 2011: 48-49). Improvisational exercise tehnique push the student to utilize a number of skills at once. This is why this strategy can stimulate students' oral activities. Role-playing can provide them with a clear way to express their ideas freely, and use their oral expressions deeply to exert their imagination in different contexts and situations. Therefore, the researcher proposes modified Role Play strategy, which is in line with the approach of Role Play and improv card, in order to make the output better. It will also stimulate students' idea in speaking. 


\section{Procedures of Teaching Speaking through modified Role Play strategy}

These steps in modified Role Play strategy are combination of Huang (2008). The integrated procedures can be described as follows:

Prepare Class for Role Play

a. The teacher provides some samples of Role Play Activity. It concludes situation or event that represent some aspect of reality.

b. Students are asked to mention some activities that happen in their real life.

c. The teacher defines the problem, situation, and role clearly.

d. The teachers tells students about Improv card that they will get in the middle of role play

e. The teachers gives the example of Improv card and tells student to react based on the card they get. For example "you are sick, you get fever" so the students have to react in that situation and continue the conversation.

Give clear instructions

a. The teacher chooses the situation according to the material to be discussed.

b. The teacher explained and exemplified the situation to play.

c. The teacher will explain the vocabulary, sentences and dialogue needed for the role-playing situation.

d. The teacher divides the students into groups or pairs

Act out

a. students are asked to practice with their partner

b. students are asked to assume the roles and spontaneously "live" the situation

c. the teacher asks some of the students to practice in front of the class

d. the teacher gives improv card in the middle of role play

e. the students are asked to react with that situation and modify the role play

Discussion and Evaluation

a. Students are asked to answer a few basic information about the roleplaying activity.

b. Students are asked to re-enact the role plays

c. Students are given the task of translating the role plays into their native language. 
In considering the original model design and the modified one, the researcher conducts the two designs of role play Technique, in which the designs are different. The researcher develops two parts, it is by adding the IMPROV card.

\section{Methods}

\section{Participants}

The population of this research is the students at the pre-intermediate level who have passed elementary class for 3 months in the English daily conversation class of Just Speak course. There are six classes; each class consists of 10-12 students. The writer used two classes as the basis for picking the participant in the research. The classes were chosen by using purposive sampling.

\section{Instruments}

In collecting data, the researcher administrated a speaking test. The speaking test here, the researcher asked the students to describe people in 2 minutes. the theme for the pre test was entertainer and the theme for the post test was politician. the speaking test was did as twice times beforeand after giving material. The data were collected after the giving instruments of speaking test.

\section{Data analysis}

The researcher used quantitative data analysis to interpret the data gathered, according to the types of data gathered. The author evaluated the data for and research question in order to explicitly answer it while evaluating the collected data. Furthermore, after assessing its normality, a repeated measure test was used to assess the difference between the speaking pre- and post-tests. The Independent Group T-test was used to compare the post-test findings for both groups. Finally, the researcher drew conclusions from the data.

\section{Results and discussions}

\section{Improvement of the Students' Speaking Achievement after the Students were Taught through Modified Role Play}

Speaking pretest and posttest were administered to examine students' performance in speaking, before and after the treatment in each class. The tests administered took form of describing people with the topic of entertainer and politician. Therefore, the students were required to compose a monologue based on the topic. Each class (control and experimental classes) had different treatment with similar material. Students in control class were taught by original Role Play. While in experimental class, students were taught by using modified 
Role Play. Here is the explanation of speaking achievement analysis shown in table 1.

Table 1 Students' Speaking achievement

\begin{tabular}{ccccccc}
\hline \multirow{2}{*}{ No } & \multirow{2}{*}{ Interval } & \multicolumn{2}{c}{ Control Class } & \multicolumn{2}{c}{ Experimental Class } & \multirow{2}{*}{ Interpretation } \\
\cline { 3 - 6 } & & Pre & Post & Pre & Post & \\
\hline 1 & $41-47$ & 4 & O & 2 & 0 & Poor \\
\hline 2 & $48-54$ & 6 & o & 5 & 0 & Poor, fair \\
\hline 3 & $55-61$ & 2 & o & 5 & 0 & sufficient \\
\hline 4 & $62-68$ & 1 & 4 & 2 & 1 & sufficient \\
\hline 5 & $69-75$ & 1 & 5 & o & 1 & good \\
\hline 6 & $76-82$ & o & 5 & o & 9 & good \\
\hline 7 & $83-89$ & o & o & o & 2 & Very good \\
\hline 8 & $90-96$ & o & o & o & 1 & Excellent \\
\hline
\end{tabular}

Table 1 shows the improvement of students' speaking achievement between two tests (pretest and posttest) in each class (experimental class and control class). The data shows that most of students from each class in pretest were below the speaking standard score (61). This means all the students were not ready enough to have a speaking test which is in form of describing people. However, students got better in speaking achievement after the treatments.

During the pretest, in control class most of the students (10 students) got speaking score between 41 until 54 . While in experimental class, there were 10 students. Then, the student who got the highest score in the pretest are in the fourth interval. In control class, there were 2 students passed and got score between 62 and 75. While in experimental class, there were 2 students who are in the fourth interval. The first interval (the lowest interval), there were 4 students (in control class) and there were 2 students (in experimental class). However, over the five meetings, students got better in speaking achievement after the treatments.

The implementation of Role Play, during speaking pretest, the students were below the speaking standard with most of students are in the second interval $(48-54)$. However during speaking posttest, there was improvement of students' speaking achievement after the treatments. All of students achieved score above the standard ( 4 students achieved score 62 - 68, 5 students achieved score 6975 , and 5 students achieved score $76-82$ ). Most students were placed in the fifth and sixth interval which interpreted as good score.

While in the implementation of Modified Role Play, during the speaking pretest, most of the students are below standard (60). However, after the treatments, all of students got score above the standard. Most of the students scored around standard $(76-82)$. In addition, there are 2 students who get scored $83-89$. Moreover, there is only one student who scored the highest interval $(90-96)$. To examine the difference of students' speaking achievement 
in each class and each test, the data were analyzed for its normality significance first. It is used to examine whether the data were normally distributed or not. The normality test was used to determine if the data were distributed or not. The data were checked for normality using Shapiro-Wilk (SPSS 25). The researcher concluded that the data from this study were normally distributed. Based on the result of the normality data test, it was found that the results were as follow: .248, $.894, .342, .666$ for pretest of control class and experimental class, and also posttest of control class and experimental class respectively. Since the significant level is higher than 0.05 , it could be assumed that the data were normally distributed.

Table 2 Normality of Speaking Test

\begin{tabular}{llccc}
\hline & Class & \multicolumn{3}{c}{ Shapiro-Wilk } \\
\cline { 3 - 5 } & & Static & df & Sig. \\
\hline $\begin{array}{c}\text { Speaking } \\
\text { Pre test }\end{array}$ & Control Class &, 924 & 14 &, 248 \\
\cline { 2 - 5 } & Experimental Class &, 971 & 14 &, 894 \\
\hline $\begin{array}{c}\text { Speaking } \\
\text { Post test }\end{array}$ & Control Class &, 924 & 14 &, 342 \\
\hline
\end{tabular}

In addition to examine whether the post test of experimental class and control class, the pretest of each class should be examined of their homogeneity variance. Levene's test was used on SPSS 25. The significant level showed that .434 , it means that the test is considered to be homogeny. Therefore, the posttest of each class can be compared.

Table 3 Test of Homogeneity of Speaking Test

\begin{tabular}{cccc}
\hline \multicolumn{4}{c}{ Anxiety Level Questionnaire } \\
\hline $\begin{array}{c}\text { Levene } \\
\text { Statistic }\end{array}$ & df1 & df2 & Sig. \\
\hline 0,632 & 1 & 26 &, 434 \\
\hline
\end{tabular}

After analyzing the normality and homogeneity of the pretest of each class, the result of the speaking tests were analyzed to answer tested the hypotheses. The hypothesis of the study is to examine whether there is significant difference of students' speaking achievement after the implementation of Modified Role Play. Repeated measure t-test was applied to examine the difference of each test and class. There are two pairs which are examined 1) first pair is pretest and posttest of control class; 2) second pair is pretest and posttest of experimental class. The independent $t$ test was used to examined the posttest between 2 class (experimental and control). Based on the analysis from SPSS, the result as follows .000, .000, .010 for the first, second, and third pair respectively. Based on the 
result, it could be implied that both control and experimental class showed significant differences between pretest and posttest (for the first and second pair). In addition, there was improvement of students' speaking achievement as shown that the $t$-level is higher than the $t$-table. It shows that the $t$-level for the first pair is 12,156 and for the second pair 22.481. The two t-levels are higher than the $t$ table (2.145) which means there is improvement of students' speaking achievement. In addition, for the third pair (comparison of the posttest between control and experimental class, it shows that there is significant difference for each class since the significant level is lower than the alpha level $(.011<.05)$. In addition, the students taught by modified role play showed better improvement than the students taught by original podcast procedure. It could be inferred from the $t$-level is bigger than the $t$-table $(2.720>2.145)$. Therefore, it could be implied that the implementation of modified Role Play in teaching speaking is better than original Role Play in improving students' speaking achievement.

Table 4 Difference of Speaking Test

\begin{tabular}{|c|c|c|c|c|c|}
\hline & & Mean & $\mathrm{t}$ & $\mathrm{df}$ & Sig. (2-tailed) \\
\hline $\begin{array}{l}\text { Pair } 1 \\
\text { Control Class }\end{array}$ & $\begin{array}{l}\text { Pretest } \\
\text { Posttest }\end{array}$ & $-20,143$ & 12,156 & 13 & , OOO \\
\hline $\begin{array}{l}\text { Pair } 2 \\
\text { Experimental Class }\end{array}$ & $\begin{array}{l}\text { Pretest } \\
\text { Posttest }\end{array}$ & 24,571 & 22,481 & 13 & ,0O \\
\hline
\end{tabular}

Table 5 Independent T-Test

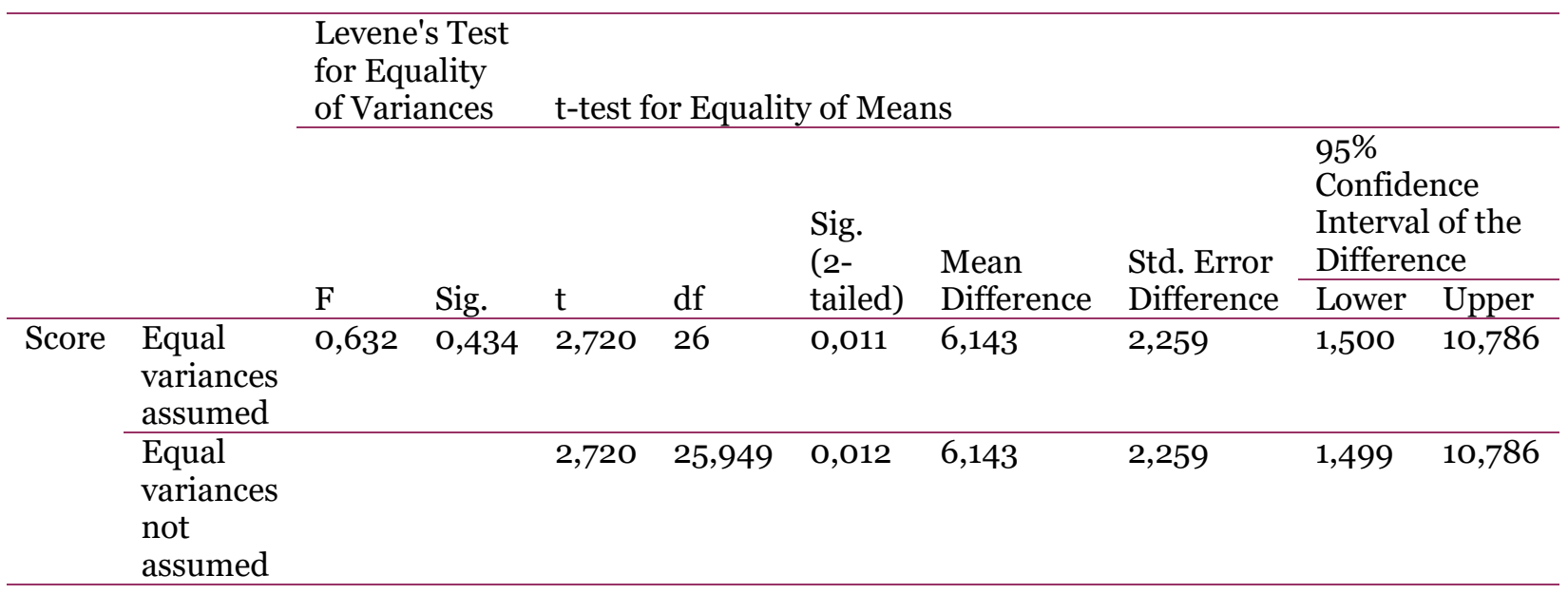

After comparing each test in each class, it could be inferred that the implementation of Role Play can improve students' speaking achievement. Moreover, experimental class which was taught through modified Role Play shows better improvement of students' speaking achievement. 
In addition, the difference of the students' speaking achievement in each aspects after being taught through Original Role Play and modified Modified Role Play was also investigated by the researcher. The researcher focused on aspects (Pronunciation, grammar, vocabulary, fluency, and comprehension). The data were obtained from the students' speaking achievement.

\begin{tabular}{lllllll}
\hline \multirow{2}{*}{$\begin{array}{l}\text { Aspects } \\
\text { Speaking }\end{array}$} & of & \multicolumn{2}{l}{ EXPERIMENTAL } & \multicolumn{4}{l}{ CONTROL } \\
\cline { 2 - 8 } & $\begin{array}{l}\text { Mean of } \\
\text { Pretest }\end{array}$ & $\begin{array}{l}\text { Mean of } \\
\text { Posttest }\end{array}$ & Gain & $\begin{array}{l}\text { Mean of } \\
\text { Pretest }\end{array}$ & $\begin{array}{l}\text { Mean of } \\
\text { Posttest }\end{array}$ & Gain \\
\hline Pronunciation & 11.25 & 15.85 & 4.6 & 10.78 & 14.75 & 3.97 \\
\hline Grammar & 10.57 & 15.53 & 4.96 & 10.32 & 14.10 & 3.78 \\
\hline Vocabulary & 10.5 & 15.57 & 5.07 & 10.42 & 14 & 3.58 \\
\hline Fluency & 10.57 & 15.64 & 5.07 & 10.32 & 14.35 & 4.03 \\
\hline Comprehension & 11.10 & 15.92 & 4.92 & 10.5 & 15.21 & 4.71 \\
\hline Total & $\mathbf{5 3 . 9 9}$ & $\mathbf{7 8 . 5 1}$ & $\mathbf{2 4 . 6 2}$ & $\mathbf{5 2 . 3 4}$ & $\mathbf{7 2 . 4 1}$ & $\mathbf{2 0 . 0 7}$ \\
\hline
\end{tabular}

From the table above, it can be seen that the students' speaking achievement for both control and experimental class have significant differences.The students who are taught with the modified Role Play have the higher increases in all aspect respectively than the students who are taught with the original Role Play

\section{Discussion on how students' speaking abilities improved after they were taught in a modified role play.}

Having analyzed the result of students' speaking achievement in pretest and posttest from each class (experimental and control class), it is found that there was significant difference of students' speaking achievement. In addition, there was improvement of students' speaking achievement after the implementation Role Play and modified Role Play. However, there was a difference of students' speaking achievement improvement from each class. In the process of teaching both class, the researcher used online platform such as zoom and google meet. The researcher adapted the situation because of coronavirus. Coronavirus or COVID-19 has attacked the world since the end of 2019. This virus was first discovered in Wuhan, Hubei, China. there are 95,124 people are exposed worldwide (CNN, 2020). As a result of the COVID-19 pandemic, the entire system has been changing. In particular, education in Indonesia is being disrupted. As of March 11, 2020, the President of the Republic of Indonesia implemented a strategy of temporarily suspending teaching and studying in schools and colleges, allowing students to study at home with online learning in order to break the virus chain. 
In this research, the researcher used online platform google meet to do the pretest and posttest since the application was already in students phone connected with gmail. The researcher called students one by one by listing time and name. The students had to describe someone by turning on their camera and their eyes had to focus on camera. Surprisingly, all of students did great job and followed the rules given. During the pretest, in both classes, it was evidenced that most students were difficult to express their idea due to the high anxiety level and low self-confidence that they possessed. In short, students who were influenced by the low level of WTC would find it difficult to join the activity. Hence, this condition resulted in the production of speaking. Students needs to have the willingness to communicate to deal with the speaking aspects. This result is in line with several previous study. Thousi and Khalaji (2014) has investigated the impact on WTC on students' speaking ability. It is found that WTC correlates significantly with students' speaking ability. It was evidenced by the result of pretest that showed the students from both of the class had difficulty in arranging word, speaking fluently, and using proper structure of the sentences spoken. In addition, during pretest the activity, most of the students were so nervous and not confident. actually all of students actually have passed the elementary level that make students have the capability and confidence to speak up, because of pandemic they do not practice their English and ended up lose the feeling. This condition would trigger such condition where students lost their interest and capability that they had before.

After the implementation of Role Play, students showed better speaking achievement. The implementation Role Play as the teaching technique aid students' obstacles in producing the oral production such as pronunciation and selecting diction as it is believed that role play provides authentic material such as vocabulary, pronunciation, intonation in a contextual situation (Fitria\&Vianty\& Petrus, 2015; Gromik, 2008; Thomas, 2009 p.342; Fernando, 2007). In addition, those benefits are considered as a comprehensible input to students which enhance their confidence and decrease their speaking anxiety (Constantine, 2007). In addition, the implementation of role play as the teaching activity could promote students speaking achievement. this result is inline with some previous research that apply role play as their teaching activity (Shen \&Suwanthep, 2011; Arifin \&Rsnija, 2013; Krebt, 2017). Study of Shen \&Suwanthep (2011) applied constructive e-learning role play activity to improve college students. In the learning activities, students solved problems, not only in material learning, but also in integrating practical knowledge, exploring alternatives and creative solutions. In other words, students are required to have a new dialogue on the original basis. Research has found that the constructive role playing of e-learning has a positive effect on improving the oral performance of students of different language proficiency. The students did well, and they applied what they had learned in the courses and previous studies to actively and 
effectively engage in a positive e-learning role play. Study of Arifin \&Rosnija (2013) applied role play to improve senior highs school students' speaking achievement. It is found out that the implementation of role play are able to promote students' speaking achievement. In addition, they agreed that the use of role play makes teaching learning activity fun and enjoyable. This situation provides the opportunity for students to bring broader world into the classroom activity since students are able to be different characters and they are free to play it. Study of Krebt (2017) applied roleplay to improve college students' speaking achievement. They applied textual information gap where students have different gap of information which needs to be filled up. The results of this study indicated that the treatment used influenced the results; thus it can be concluded that the use of role play as a classroom technique improved the performance in the speaking test. In short, previous researchers claim that using role play as a learning activity gives students a lot of opportunities to practice their speaking skills while also shaping their attitude and confidence.

Although the implementation of role play in control class could give significant difference and improvement of students speaking achievement, during the treatment section, some students showed hesitation to join the class and sharing their idea during the class. The students had to adapt with the situation of having conversation online. The change of adaptation can be seen in the first meeting when students were not comfortable to express their idea without the sensitivity of having conversation directly face to face. After the first meeting, they tended to be relax and understood how to do the online role play by using the filter and background to make it real and exciting. Moreover, students tended to feel bored when they practiced the dialogue in the same situation. The fully participation of students is one of the biggest challenges of the role playing technique. Some of students were strong participant as well as dominant in the conversation that demotivated the others to speak up more. There was imbalance in the group when the other did not give any perspective so the conversation would not be exciting.

On the other hand, The implementation of improv activity provide students with enormous chance to access native language aspects such as vocabulary, fluency, comprehension. It is in line with the theory from Florea (2011) an improvisational activity can be a fun and effective way to attract students. It not only gives them grammatical structure, but it also helps them to communicate with one another and improve their listening, grammar, and vocabulary skills. Students normally engage well in improvisational activities as they understand the reasons for the exercises. Casteleyn (2018) stated that improvisational training is also very interesting, and by refuting them with a more positive attitude may change the perception of problematic public speech. Students can develop their oral expression skills (voice, body language, etc.) and learn how to make decisions and take chances through improvisation, which can 
help minimize the anxiety associated with public speaking and provide opportunities to inspire students to be bold in public speaking. In addition, this result is also in line with several previous study (Fauzan, 2014; Hadeli \& Eviarni, 2017). Fauzan (2014) conducted a research on implementing an improvisational technique to improve university students. Drama improvisation is a great oral teaching technique. It will help students develop their speaking skills. In English learning, he believes that fluency and accuracy are equally significant. Improving drama is extremely necessary and can help students develop their fluency. Then there's the matter of time and procedure to boost students' accuracy. According to the results of the research, it can be concluded that improvisation can improve the spoken language ability of the English Department of students of Widyagama Mahakam University Samarinda. Another research is done by Hadeli \& Eviarni (2017) implemented Improvisation technique to identify the effect on senior high school students. There were significant differences in the oral expression ability of the experimental class students who express impromptu skills and the oral expression ability of the control class students who accept conventional skills. Impromptu skills were a good way for students to develop their oral English abilities, especially when expressing interests and giving opinions. They can speak a lot in English if their vocabulary and self-confidence expand. Speaking English more has helped them boost their fluency dramatically. Then, improving their fluency is a good way to develop their speaking skills. Then, their fluency is an effective way to improve their speaking ability. In short, they agreed that the implementation of improv gives students' chance to access the native sources and also promotes students' speaking proficiency.

In addition, the implementation modified Role Play provides students with opportunities to practice their language skills. In addition, the activity in class enabled students to be active and make students' speaking fluent (Toro \& Camacho-Minuche\& Pinza \& Paredes, 2018; Farooq, 2015). In short, the more chances students have to practice their oral production activity the better students oral production will have. This result is in line with several previous research. Study from Krisdiana, Irawati, and Kadarisman (2018) conducted a research on role playing integrated with word cards. Research findings showed that the integration of role playing and word cards can help improve students' communication skills. Another study conducted by Fongl, Bhattacharyyal, and Nordin (2018) examined the effectiveness of "time-out" role-playing techniques, which can enhance speech activities in ESL classrooms. The researchers used a qualitative research design. 94 students (Secondary 4 and 5) from a secondary school in Perak played this role in the classroom environment. The results of this study showed that overtime role-playing successfully achieved the goals set in the communication aspirations outlined in the "Secondary School Oral English Proficiency" (OPS-English) and the "National Education Blueprint" (2013-2025). The result from the previous studies show positive effect by combining role play 
with other material and technique. In contrast to the previous research that applied role play as the teaching technique, this research applied improv that modified role play technique. In short, it could be inferred that the implementation of modified role play is able to boost students' confidence and promote students speaking performance. It could be inferred that the implementation of modified role play can improve students' speaking better than original role play.

\section{Conclusions and suggestions}

The implementation of each teaching program can help students improve their speaking achievement. This study provides an understanding of the implementation of modified role play used in the conversation class. The findings showed that there was a significant difference in students' speaking achievement. all of aspects of speaking improved for both of classes but modified roleplay showed better improvement. This research can be used as a reference technique for teachers or lecturers to teach oral English to students. It is hoped that this research is worthy of the knowledge of English teachers, especially in distinguishing or choosing appropriate methods, method skills and activities to teach speaking skills. As a concluding remark, it can be concluded that a modified role play needs to be implemented in the classroom. It is not only useful for students' language development, but also for their second language acquisition. For students who speak English as a second or third language, as well as students who speak English as their native tongue, role playing is especially beneficial for language growth. Role playing will also develop students' communication skills in a safe environment, as well as their vocabulary and grammar. The most successful way to learn a language is by role-playing. Although the teacher generously used role-playing and improvisation, students' preferences and practical skills were not studied here. Therefore, potential researchers should take this into consideration for further research.

\section{References}

Afdillah, N. M. (2015). The effectiveness of role play in teaching speaking [Master dissertation, Department of English Education, Faculty of Tarbiyah and Teachers' Training, Hidayatullah State Islamic University, Jakarta]. http://repository.uinjkt.ac.id/dspace/handle/123456789/26710

Aliakbari, M., - B. Jamalvandi. (2010). The impact of role play on fostering efl learners' speaking ability; a task-based approach. Journal of Pan-Pacific Association of Applied Linguistics.

Altun, M. (2015). Using role-play activities to develop speaking skills: a case study in the language classroom. Paper given at a conference, held on April 26-27, 2015 in Ishik University, Erbil, Iraq, In Book of Proceedings. 
Aswad, Muhammad. (2017). Is it truly improvisational exercise push students speaking ability. EDUVELOP (Journal of English Education and Development).

Bilbrough, N. (2007). Dialogue activities. Cambridge: Cambridge University $\backslash$ Press

Benabadji, M. (2007). Improving students'fluency through role-playing [Master Thesis, University of Oran].

Bedore, B. (2004). 101 improv games for children and adults (1st Edition ed.). (A. Mummery, Ed.) Alameda, CA, USA: Hunter House Inc.

Berlinger, M. R. (2000). Encouraging english expression through scriptbased improvisations. The Internet TESL Journal, Vol. VI, No. 4, April 2000. (http://iteslj.org/Techniques/Berlinger-ScriptImprov.html.

Casteleyn, J. (2018). Playing with improv(isational) theatre to battle public speaking stress. Research in Drama Education: The Journal of Applied Theatre and Performance.

Chaney, A. L., \& Burk, T. L. (1998). Teaching oral communication in grades $k-$ 8. Boston: Allyn and Bacon.

Constantine, M. G. (2007). Racial microaggressions against African American clients in cross-racial counseling relationships. Journal of Counseling Psychology, 54(1), 1-16.

Cook, Vivian. (2008). Second language learning and language teaching. Fourth Edition. Great Britain: Hodder Education

Dornyei, Zoltan. (2005). The psychology of the language learner. individual differences in second language acquisition. New Jersey: Mahwah.

Ellis R. (2004). Task based language learning and teaching. Oxford: Oxford University Press.

Fauzan, Umar. (2014). The use of improvisation technique to improve the speaking ability of efl students. DINAMIKA ILMU

Fernando, M. (2007). Spiritual leadership in the entrepreneurial business: a multifaith study. (1 ed.). Cheltenham, UK: Edward Elgar Publishing.

Fitria, U., Vianty, M., \& Petrus, I. (2015). Using podcast to improve students' listening and speaking achievements. The Journal of English Literacy Education (The Teaching and Learning of English as A Foreign Language, 2(1), 55-68

Florea, P. J. (2011). Using improvisational exercises for increasing speaking and listening skills. Asian EFL Journal, pp. 46-58.

Fong, L., Bhatacarya, E., \& Nondrin, S. (2018). Communication in real time: esl students' perception of "time out" role play. Pertanika $J$. Soc. Sci. \& Hum.26 (5),73

Gromik, N. (2008). EFL learner use of podcasting resources: A pilot study. The JALT CALL Journal, 4(2), 47-60.

Hadeli, H., \& Eviani, E. (2017). The effect of improvisation technique towards EFL students speaking ability. Al-Ta Lim Journal, 224 (2)

Halper, C . , Close, D . , \& Johnson, K . (1994). Truth in comedy : The manual of improvisation. Colorado Springs, CO : Meriwether Publishing, LTD .

Harmer, J. (1984). The practice of english language teaching. London: Longman.

Huang, I. Y. (2008). Role play for esl/efl children in the english classroom. The Internet TESL Journal, 14(2). http://iteslj.org/Techniques/ Huang- 
RolePlay.html.

Krebt, D. M. (2017). The effectiveness of role play techniques in teaching speaking for efl college students. Journal of Language Teaching and Research, 8(5), 863-870.

Krisdiana, B. P., Irawati, E., \& Kadarisman, A. E. (2018). The effectiveness of role-play integrated with word cards on students' speaking skill for communication. Jurnal Pendidikan Humaniora, 6(2), 78-84.

Ladousse, G. P. (1995). Role play: resources book for the teacher series. New York: Oxford University Press.

Leong, L. M., \& Ahmadi, S. M. (2017). An analysis of factors influencing learners' english speaking skill. International Journal Of Research In English Education. 2 (1)

Livingstone, C. (1983). Role play in language learning. Singapore: Longman.

Milarisa, S. (2018). The effect of using role plays technique among accounting students' speaking achievement at stie muhammadiyah berau. English Community Journal (2018), 2 (1): 183-193 185

Pamila J. Florea. (2011). Using improvisational exercises for increasing speaking skill and listening skill. Asian EFL Journal. Professional Teaching Articles-CEBU Issue. Vol.52 May 2011

Pollard, Andrew. (2008). Reflective teaching 3rd edition: evidence informed professional practice. Continuum International Publishing Group.

Qing, X. (2011). Role-play an effective approach to developing overall communicative competence. Cross-Cultural Communication.

Rahman, Nurul Ajleabbinti Abdul \&NooreinyMaaruf. (2018). The effect of roleplay and simulation approach on enhancing esl oral communiation skills. International Journal or Research in English Education. 3(3) DOI: 10.29252/ijree.3.3.63

Richards, J. C., \& Rodgers, T. S. (2001). Approaches and methods in language teaching. Cambridge: Cambridge University Press.

Sawyer, R. K. (2000). Improvisation and the creative process: Dewey, Collingwood, and the aesthetics of spontaneity. Journal of Aesthetics and Art Criticism, 58(2),149-161.

Sawyer, R. K., \& Sawyer, R. K. (2003). Improvised dialogues: emergence and creativity in conversation. Greenwood Publishing Group.

Scrivener, J. (2005). Learning teaching. Oxford: MacMillan.

Setiyadi, Bambang. (2006). Teaching english as foreign language. Yogyakarta: Graha Ilmu.

Shen L,\&Suwanthep J. (2011). E-learning constructive role play for efl learners in china's tertiary education. The Asian EFL Journal 49.

Sunardi., Arifin, Zainal., \& Rosnija, Erni. (2013). Teaching speaking ability. through role play. Pontianak: Media Neliti.

Smith, K. \& McKnight, K. S. (2009). Remembering to laugh and explore: Improvisational Activities for literacy teaching in urban classrooms. International Journal of Education \& the Arts, 10(12). http://www.ijea.org/v10n12/.

Sowden, P. T., Clements, L., Redlich, C., \& Lewis, C. (2015). Improvisation facilitates divergent thinking and creativity: Realizing a benefit of primary school arts education. Psychology of Aesthetics, Creativity, and the Arts, 9(2), 128-138. 
Toro, V., Camacho-Minuche, G., Pinza-Tapia, E., \& Paredes, F. (2018). The use of the communicative language teaching approach to improve students' oral skills. English Language Teaching, 12(1), 110.

Tousi, Seyyed Mohsen., \& Khalaji, Hamidreza. 2014. The impact of willingness to communicate on iranian efl learners speaking ability. International Research Journal of Applied and Basic Sciences, Vol, 8 (11), 1866-1869.

Ur, P. (1996) A course in language teaching: Practice and Theory. Cambridge University Press, Cambridge.

Yaffe, S. H. (1989). Drama as a teaching tool. Educational Leadership, 46, 2932. 